\title{
Influence of natural regeneration on fractal features of residue microaggregates in bauxite residue disposal areas
}

by Zhu, F., Cheng, Q., Xue, S., Li, C, Hartley, W. Wu, C and Tian, $\mathrm{T}$.

Copyright, Publisher and Additional Information: This is the author accepted manuscript. The final published version (version of record) is available online via Wiley.

Please refer to any applicable terms of use of the publisher.

DOI: https://doi.org/10.1002//dr.2848 

FEATURES OF RESIDUE MICROAGGREGATES IN BAUXITE

\title{
RESIDUE DISPOSAL AREAS
}

\author{
Zhu Feng ${ }^{1,2}$, Hou Jingtao ${ }^{1}$, Xue Sheng-guo ${ }^{1 *}$, Wang Qiongli ${ }^{1}$, William Hartley ${ }^{3}$, Wu Chuan ${ }^{1}$ \\ ${ }^{1}$ School of Metallurgy and Environment, Central South University, Changsha 410083, PR China \\ ${ }^{2}$ South China Institute of Environmental Sciences, Ministry of Environmental Protection, Guangzhou 510655, PR China \\ ${ }^{3}$ Crop and Environment Sciences Department, Harper Adams University, Newport, Shropshire, TF10 8NB, United Kingdom
}

\begin{abstract}
Bauxite residue is often physically degraded, which limits vegetation establishment on the disposal areas. Microaggregate stability is an important physical property due to its significant effect on erosion and surface runoff, however this is rarely reported for bauxite residue. Native plant encroachment on a bauxite residue disposal area in Central China has revealed that natural regeneration may ameliorate the residue and help to support plant growth. Residue samples from five different disposal ages were collected to determine microaggregate stability and identify their fractal features. Following natural regeneration, the aggregate fraction 250-50 $\mu \mathrm{m}$ increased significantly from $27.4 \%$ to $40.3 \%$, whilst the silt+clay size aggregate fraction decreased from $58.4 \%$ to $30.7 \%$. With increasing disposal age, the residue clay dispersion ratio (CDR) ranged from $7.7 \%$ to $22.5 \%$, whilst aggregated silt and clay (ASC) ranged from $15.3 \%$ to $19.0 \%$ indicating a stable microaggregate structure. The single-fractal dimension (D) of the residues for different disposal ages varied from 2.2 to 2.4. The high $\mathrm{pH}$ and salinity of bauxite residue indicated a high value of single-fractal dimension. The multi-fractal parameters of residue microaggregates, including capacity dimension $\left(\mathrm{D}_{0}\right)$, information dimension $\left(\mathrm{D}_{1}\right)$ and information dimension/capacity dimension $\left(\mathrm{D}_{1} / \mathrm{D}_{0}\right)$ decreased which resulted in homogeneity following natural regeneration. Correlation analysis revealed that both single- and multi-fractal dimensions had significant correlations with residue microaggregate stability. Our results suggested that natural regeneration may improve microaggregate stability of bauxite residue, and fractal parameters of residue microaggregates may be used to describe residue microaggregate stability and the physical condition of bauxite residue.
\end{abstract}

KEY WORDS: Bauxite residue disposal area; bauxite residue; natural regeneration; microaggregate stability; fractal features

* Corresponding authors

E-mail: sgxue70@hotmail.com; sgxue@csu.edu.cn (Sheng-guo Xue) 
Residues from mineral ore processing are disposed on land in large residue disposal areas which may eventually create a series of ecological and environmental issues (Smart et al., 2016; Wu et al., 2016). In the aluminum industry, bauxite residue is an alkaline solid by-product generated when alumina is extracted from bauxite ore by the Bayer process (Goloran et al., 2016; Kong et al., 2017a). The global inventory has reached 3.4 billion tons, with an annual increase of 120 million tons (Xue et al., 2016a; Kong et al., 2017b). Large volumes of bauxite residue are deposited in bauxite residue disposal areas which cause potential environmental risks, as these bare areas are sensitive to erosion by wind and water, and can be regarded as a potential source of contamination due to their high alkalinity and salinity (Gelencsér et al. 2011; Ruyters et al. 2011). In situ rehabilitation and revegetation may however stabilize the residue surface and minimize wind erosion (Courtney et al., 2009; Kaur et al., 2016; Schmalenberger et al., 2013). Its poor physical structure is nevertheless a major limitation to support plant growth (Liu et al., 2013; Zhu et al., 2016a). Residue particle sizes range from 2 to 2000 $\mu \mathrm{m}$ and $60-80 \%$ exist as $<20 \mu \mathrm{m}$ (Xue et al., 2016b). Jones et al. (2011) reported that addition of organic waste may influence aggregate size distribution and increase the proportion of water-stable aggregates. Zhu et al. (2016b) found that natural regeneration may improve the physical condition and aggregate stability of bauxite residue.

Soil aggregate stability is one of the most important properties in soils and affects water erosion, soil aeration, nutrient recycling and biological activity, as well as plant growth (Cerdà 2000; Le Guillou et al., 2012; Moncada et al., 2013). Physical forces, chemical bonds and biological agents may drive the aggregation processes of soil particles (Yagüe et al., 2016; Lehmann \& Rillig, 2015). Microaggregate stability is an important soil property which is usually used to determine soil erosion resistance (Wang et al., 2016). A better understanding of microaggregate formation is essential to maintain structural stability in soils. Several major binding agents such as clay minerals, organic carbon and polyvalent ions have significant effects on colloid flocculation (Zhou et al., 2005). Barbosa et al. (2015) observed a cementation effect by organic carbon from poultry manure applications and clay flocculation enhancing aggregation. Igwe et al. (2009) discovered that oxalate and pyrophosphate extractable iron-aluminum oxides may act as aggregation agents to colloidal stability; organic carbon had acted in association with the oxides as a linkage with clay particles and polyvalent cations to enhance aggregate stability. Virto et al. (2008) concluded that stable microaggregates were formed within the silt-size fraction and organic carbon was stored by adsorption and entrapment of fine organic residues.

Soil structure is related to the size, shape and stability of soil aggregates (Aksakal et al., 2016; Ahmadi et al., 2011). Microaggregate stability depends on the size distribution of microaggregates and several procedures have been proposed for characterizing aggregate size distribution. Fractal theory is mainly used to analyze the relationship between local and overall irregular broken complex images and structural geometry under different scales. The concept of fractal dimension was proposed to provide a quantitative description for irregular shapes (Jing et al., 2016). Fractal theory has been widely applied in soil science to quantify and estimate aggregate size distribution of soils (Kolay \& Kayabali, 2006). Fractal dimension reveals the difference between particle size distribution and related physical properties (Wei et al., 2016; Wang et al., 2015). Gao et al. (2014) suggested that fractal dimension could be regarded as a considerable and reliable parameter to reflect variations in soil properties. High 
values represent aggregates dominated by fine fragments, whilst low values represent large fragments. Many researchers have used fractal dimension to predict soil particle size distribution or the size distribution of water-stable aggregates (Peng et al., 2014).

With the development of soil fractal theory, the limitation of single-fractal dimension has been stressed to describe soil particle size distribution. In order to obtain more detailed information of soil structure, multi-fractal theory was introduced to soil science (Li et al., 2016). Rodrí guez-Lado \& Lado (2016) found that particle size distribution behaved as multi-fractals, with scaling properties varying in different soil samples, whilst values of fractal dimension may be related to the degree of evolution of the soils. Peng et al. (2014) found that the single- and multi-fractal parameters could describe soil particle size distribution and the influences of soil structure effectively. There are, however, few studies focusing on multi-fractal parameters of microaggregate size distribution.

This work focuses on an alumina refinery in Central China. The inventory of bauxite residue is an estimated 35 million tons, which is currently increasing by approximately 2.2 million tons per annum (Zhu et al., 2016b). Bauxite ore is discharged in hot $\mathrm{NaOH}$ by the Bayer processes and the residues are pumped to the disposal areas using the dry stacking method. Spontaneous vegetation colonization over the past 20 years at the study site may reveal that natural weathering processes ameliorate the residue substrate and support plant growth. Natural regeneration also enhances the proportion of water-stable aggregates and resistance to erosion (Zhu et al., 2016c). As microaggregate stability is used to predict soil surface erosion (Wang et al., 2016), this study focus on 1) the effect of natural weathering processes on microaggregate stability of bauxite residue; 2) to evaluate microaggregate size distribution in bauxite residue by fractal parameters; 3) to investigate whether fractal parameters may be used as an indicator to evaluate microaggregate stability of bauxite residue.

\section{MATERIALS AND METHODS}

\section{Soil Sampling}

Residue samples were collected from a disposal area in Central China. The climate is temperate continental monsoon, with a mean annual daily temperature of $12.8^{\circ} \mathrm{C}-14.8^{\circ} \mathrm{C}$ and average precipitation ranging from $600 \mathrm{~mm}$ to $1200 \mathrm{~mm}$ per year.

According to ecological field investigations, five different zones related to disposal age were selected during August to September 2014. These included (a) 1-year-old bauxite residue (R1), (b) 4year-old bauxite residue (R2), (c) 6-year-old bauxite residue (R3), (d) 10-year-old bauxite residue (R4), and (e) 20-year-old bauxite residue (R5). Each zone was approximately $1500 \mathrm{~m}^{2}$. Within the zones, natural colonization only occurred in R5. For each zone, five random points, taken within $100 \mathrm{~m} \times 100$ $\mathrm{m}$, were designated as the replicates. For each sampling point, the residues were sampled with an auger to a depth of $20 \mathrm{~cm}$. The samples were then stored in polyethylene bags, returned to the laboratory, air dried at room temperature for two weeks and then subsequently passed through a $2 \mathrm{~mm}$ sieve prior to analysis.

\section{Physical and chemical analysis}

Mechanical composition of residue samples were analyzed using a Malvern Mastersizer 2000 (Malvern Instruments Ltd., UK) (Santini and Fey, 2013). pH and electrical conductivity (EC) of residue samples were determined in 1:5 solid/solution extracts. Exchangeable $\mathrm{Ca}^{2+}, \mathrm{Mg}^{2+}, \mathrm{K}^{+}$, and $\mathrm{Na}^{+}$were extracted with $1 \mathrm{M}$ ammonium acetate and analyzed by ICP-AES (Jones et al., 2011). Exchangeable 
sodium percentage (ESP) was calculated as the percentage of exchangeable $\mathrm{Na}^{+}$in the total exchangeable cations. The total contents of $\mathrm{Ca}, \mathrm{Mg}, \mathrm{K}$ and $\mathrm{Na}$ in bauxite residue were determined after microwave digestion using $\mathrm{HF}, \mathrm{HCl}$ and $\mathrm{HNO}_{3}$ and analysed by ICP-AES (Jones et al., 2011). Total organic carbon was measured by the low-temperature external-heat potassium dichromate oxidation colorimetric method (Zhu et al., 2016a). Chemical phases of residue samples were determined by X-ray powder diffraction (XRD) on a Bruker D8 discover 2500. XRD patterns were collected from $10^{\circ}$ to $80^{\circ}$ at a step size of $0.04^{\circ} 2 \theta$ with a scan rate of $1^{\circ} 2 \theta$ per minute and analysed using PANalytical analysis package (Zhu et al., 2017).

\section{Microaggregate Stability Analysis}

Laser sizing (for the $<0.25 \mathrm{~mm}$ fraction) was used to determine particle size distribution of residue microaggregates (Santini \& Fey, 2013). In this method, $10 \mathrm{~g}$ of air-dried residue samples were placed in a $0.25 \mathrm{~mm}$ sieve. The residue samples were then immersed in distilled water and oscillated for $24 \mathrm{~h}$ using an end-over-end shaker with a rate of 200 cycles per minute. Particle size distribution of the $<0.25 \mathrm{~mm}$ aggregates was determined using a Malvern Mastersizer 2000. In order to observe residue microaggregate distribution characterization under natural regeneration, micro-morphological studies of the residue microaggregates from R1 and R5 were examined using a FET Quanta-200 scanning electron microscope (SEM), equipped with energy dispersive X-ray spectroscopy. The specimen was sputter coated with a layer of gold prior to examination (Zhu et al., 2016b).

Water-dispersible clay (WDC) and water-dispersible silt (WDSI) were determined as the proportion of clay and silt in suspension in the distilled water. Clay dispersion ratio (CDR) and aggregated silt+clay indices (ASC) were selected as the two indicators to measure microaggregate stability of bauxite residue. Clay dispersion ratio (CDR) was determined as the following equation (Cammeraat \& Imeson, 1998):

$$
\operatorname{CDR}(\%)=\frac{\% \text { clay }+\% \text { silt }(\text { water dispersed })}{\% \text { clay }+\% \text { silt }(\text { calgon dispersed })} \times 100
$$

This is defined as the percentage ratio of clay+silt $(<0.02 \mathrm{~mm})$ obtained from both distilled water and sodium hexametaphosphate (calgon) dispersed residue samples. The value of ASC was negatively correlated to aggregate stability (Mbagwu \& Auerswald, 1999).

Aggregated silt and clay (ASC) was calculated using the following equation:

$$
\operatorname{ASC}(\%)=(\% \text { clay }+\% \text { silt })(\text { calgon dispersed })-(\% \text { clay }+\% \text { silt })(\text { water dispersed })
$$

A higher ASC value indicates greater microaggregate stability (Monreal et al., 1995).

\section{Calculation of Single-fractal Dimension (D)}

The power-law relationship between either number-diameter, mass-diameter or bulk density-diameter of soil aggregates are always used to determine the fractal dimension of soil aggregates. Here, according to Tyler \& Wheatcarft (1989), mass-diameter of residue aggregates was selected to calculate the fractal dimension of microaggregates, designated as D, as follows:

$$
\mathrm{D}=3-\lg \left(\mathrm{W}_{\mathrm{i}} / \mathrm{W}_{\mathrm{o}}\right) / \lg \left(\overline{\mathrm{d}}_{\mathrm{i}} / \overline{\mathrm{d}}_{\max }\right)
$$

where $\mathrm{D}$ is the mass fractal dimension; $\mathrm{W}_{\mathrm{i}}$ is the cumulative mass of the $<\mathrm{d}_{\mathrm{i}}$ residue aggregates; $\mathrm{W}_{\mathrm{o}}$ is the total mass of the residue aggregates; $\overline{\mathrm{d}}_{\mathrm{i}}$ is the mean diameter of aggregates in adjacent particles 
and $\overline{\mathrm{d}}_{\max }$ is the mean diameter of the largest aggregates.

\section{Calculation of Multi-fractal Parameters}

In this study, the measurement interval of the laser particle size analyzer $(\mathrm{I}=[0.01 \mu \mathrm{m}, 250 \mu \mathrm{m}])$ was considered as the residue microaggregate size volume percentages obtained from the previous results. The miacroaggregate size interval is divided into 74 subintervals $I_{\mathrm{i}}=\left[\varphi_{\mathrm{i}}, \varphi_{\mathrm{i}+1}\right], \mathrm{i}=1,2, \ldots, 74$. Based on standard microaggregate-size division methods, $\log \left(\varphi_{i+1} / \varphi_{i}\right)$ is the constant following the measurement interval of $I=[0.01,250]$. In order to build a new measurement of the multi-fractal method, $\psi \mathrm{i}=\log \left(\varphi \mathrm{i} / \varphi_{1}\right)(\mathrm{i}=1,2, \ldots, 74)$ was created to form a new dimensionless interval of $\mathrm{J}=[0,4.40]$, which had 74 subintervals of equal length, $\mathrm{Ji}=\left[\psi_{\mathrm{i}}, \psi_{\mathrm{i}+1}\right](\mathrm{i}=1,2, \ldots, 74)$. In the interval $\mathrm{J}$, $\varepsilon$ was defined as $2^{\mathrm{k}}$ same size subintervals, $\varepsilon=4.4 \times 2^{-\mathrm{k}}$. The value of $\mathrm{k}$ ranged from 1 to 6 to make sure that every subinterval contained at least one measured value (Peng et al., 2014). Thus, the multi-fractal parameters including capacity dimension $\left(\mathrm{D}_{0}\right)$, information dimension $\left(\mathrm{D}_{1}\right)$, correlation dimension $\left(\mathrm{D}_{2}\right)$ and information dimension/capacity dimension $\left(\mathrm{D}_{1} / \mathrm{D}_{0}\right)$ were calculated as the following equations (Ahmadi et al., 2011):

$$
\begin{aligned}
& D(q) \approx \lim _{\varepsilon \rightarrow 0} \frac{1}{q-1} \times \frac{\log \left[\sum_{i=1}^{n(\varepsilon)} u_{i}(\varepsilon)^{q}\right]}{\log \varepsilon} \quad q \neq 1 \\
& D_{1} \approx \frac{\sum_{i=1}^{n(\varepsilon)} u_{i}(\varepsilon) \log u_{i}(\varepsilon) \quad q=1}{\log \varepsilon} \quad q=1
\end{aligned}
$$

The value of $q$ varied between -10 and 10 with a step size of 1 . The multi-fractal spectrum of the residue microaggregate size distribution were determined by $D(q)$. $D_{0}$ indicated the span of the residue microaggregate size distribution and the larger $D_{0}$ value representing a wider range; $D_{1}$ indicated the irregular degree of the residue microaggregate size distribution and the higher $\mathrm{D}_{1}$ representing a higher level of dispersion in microaggregate size distribution; $\mathrm{D}_{1} / \mathrm{D}_{0}$ can measure the degree of heterogeneity of microaggregate size distribution (Peng et al., 2014).

\section{Data Analysis}

All analyses were performed in quintuplicate. The data were statistically treated with Microsoft Excel 2003, SPSS version 19.0 and Origin 8.0. A two-way ANOVA, followed by Tukey's post hoc test was used to determine the interaction between fragment size range and residue disposal ages. Chemical properties of bauxite residue samples with different chronosequences were individually determined using one-way ANOVA followed by Tukey's post hoc tests. In the case of no homogeneity, Dunnett's T3 test was performed. Bivariate correlation analyses were used to determine the relationships between fractal parameters and residue microaggregate size distribution. All figures were constructed using Origin 8.0 .

\section{RESULTS AND DISCUSSION}

\section{Particle Size Distribution of Residue Microaggregates}

The particle size distribution of microaggregates is shown in Table I . The main fraction, $<0.02$ $\mathrm{mm}$ aggregates, accounted for more than $55 \%$ of the total microaggregate weight in newly stacked 
residue (R1). Microaggregate fractions in the fresh residue (R1) decreased in the following order, 250-50 $\mu \mathrm{m}>10-5 \mu \mathrm{m}>20-10 \mu \mathrm{m}>5-2 \mu \mathrm{m}>50-20 \mu \mathrm{m}><2 \mu \mathrm{m}$. With increasing disposal age, the aggregate fraction $250-50 \mu \mathrm{m}$, increased significantly from $27.4 \%$ to $40.3 \%$, whilst the clay-size aggregate fraction decreased gradually. Microaggregate fractions which had been disposed for 20 years (R5) decreased in the following order, $250-50 \mu \mathrm{m}>50-20 \mu \mathrm{m}>20-10 \mu \mathrm{m}>10-5 \mu \mathrm{m}>5-2 \mu \mathrm{m}><2$ $\mu \mathrm{m}$. With increasing disposal age, the fine particles of bauxite residue became coarser and the silt+clay size $(<0.02 \mathrm{~mm})$ aggregate fraction effectively decreased.

SEM images of residue microaggregates from R1 and R5 are shown in Fig. 1. The residue microaggregate in R1 contained numerous amorphous substances and fine particles. Compared to R1, the microaggregate in R5 consisted of a great number of larger aggregates. With increasing disposal age, the residue microaggregates had a denser structure and the particles were distributed uniformly. Total sodium content decreased from $9.27 \%$ to $1.07 \%$, whilst total calcium content increased from $13.89 \%$ to $27.88 \%$ (Fig. 1), which suggested that natural weathering processes decreased sodium but increased calcium content. The result from Fig. 1 was consistent with the variation trend of calcium and sodium content in Table II.

Natural weathering processes may have a positive effect on particle aggregation; the finer particles aggregating to form larger particles (Santini \& Fey, 2013). Climate affects soil aggregation through alterations in temperature and moisture regimes and wet-dry and freeze-thaw cycles, which can re-orientate particles and improve aggregation (Singer et al., 1992). Weathering alters materials, which are translocated within the soil through leaching, eluviation, and illuviation resulting in horizonation (Garcia-Franco et al., 2015; Zhou et al., 2017). Plant roots and their rhizospheres have positive effects on soil aggregation. Roots realign soil particles and release exudates, which result in physical, chemical and biological alterations that influence aggregation (Rillig et al., 2001). Courtney et al. (2009) revealed that gypsum and spent mushroom compost application may decrease microaggregate breakdown and hence the dominance of less erodible aggregates. Courtney et al. (2013) found that addition of gypsum and compost produced a significant decrease in clay- and silt-size particles, whilst mean particle size $(<53 \mu \mathrm{m})$ was lowest in the unamended residues. Natural weathering processes may ameliorate physical and chemical properties of bauxite residue, which lead to clay-size particles flocculating and the formation of more stable aggregates.

\section{Microaggregate Stability of the Residues}

Colloidal stability indices of the residues are presented in Fig. 2. Water-dispersible clay (WDC) which was used to estimate microaggregate instability, ranged from $0.64 \%$ to $2.04 \%$, whilst water-dispersible silt (WDSI), also used to estimate instability, ranged from $30.72 \%$ to $58.39 \%$. A combination of WDC and WDSI gave values of between $31.4 \%$ and $58.4 \%$. Clay dispersion ratio (CDR) of the residues ranged from $7.7 \%$ to $22.5 \%$, and aggregated silt and clay (ASC) ranged from $15.3 \%$ to $19 \%$. Following natural disposal processes, WDC, WDSI, CDR and ASC of the residues stacked for 20 years (R5) increased by $218.75 \%, 90.07 \%, 192.21 \%$ and $24.18 \%$, respectively.

The WDC, WDSI, CDR and ASC may be used to estimate the rate of soil dispersibility. A high WDC and dispersion indices have negative implications for the soil environment in terms of water and wind erosion (Virto et al., 2008). With increasing disposal age, WDC, WDSI and CDR significantly decreased, whilst ASC increased indicating that natural stacking processes may improve microaggregate stability; the finer particles may combine together to form larger particles due to binding agents related to physical and chemical properties of the residues (Zhu et al., 2016c). Plant 
growth and root penetration may also have positive effects on particle aggregation and stability as the residues stacked for 20 years (R5) had improved colloidal stability compared to the other locations.

Stability of microaggregates, as opposed to its dispersion, is a very important soil property that regulates soil degradation. Several major binding agents including clay content, organic carbon and electrolytes had significant effects on microaggregate stability. Clay content, organic carbon, $\mathrm{pH}$ and exchangeable cations were selected to identify correlational relationships with colloidal stability indices. The selected physical and chemical properties were determined in a previous study (Zhu et al., 2016c). Silt and clay contents ranged from 48.8\%-23.8\% and 5.9\%-1.5\% respectively. With increasing disposal age, $\mathrm{pH}$ and EC were significantly reduced. Total organic carbon (TOC) content ranged from $5.7-10.8 \mathrm{~g} / \mathrm{kg}$. Exchangeable $\mathrm{Ca}$ and $\mathrm{Na}$ varied regularly but with opposite trends (Table II).

As natural weathering processes had a significant effect on bauxite residue mineral chemistry, the residue samples, including $\mathrm{R} 1$ and $\mathrm{R} 5$, were selected to investigate the variation in chemical phases (Figure 3). Slaked lime addition by the Bayer process resulted in the formation of calcium minerals including calcite $\left(\mathrm{CaCO}_{3}\right)$, hydrogarnet $\left(\mathrm{Ca}_{3} \mathrm{Al}_{2}\left(\mathrm{SiO}_{4}\right)_{\mathrm{x}}(\mathrm{OH})_{12-4 \mathrm{x}}\right)$, and tri-calcium aluminate $\left(\mathrm{Ca}_{3} \mathrm{Al}_{2}(\mathrm{OH})_{12}\right)$. Other alkaline minerals in the residue included sodalite $\left(\mathrm{Na}_{6} \mathrm{Al}_{6} \mathrm{Si}_{6} \mathrm{O}_{24} \cdot[2 \mathrm{NaOH}\right.$ or $\left.\left.\mathrm{Na}_{2} \mathrm{CO}_{3}\right]\right)$ and cancrinite $\left(\mathrm{Na}_{6} \mathrm{Al}_{6} \mathrm{Si}_{6} \mathrm{O}_{24} \cdot 2 \mathrm{CaCO}_{3}\right)$. Following natural processes, sodalite, hydrogarnet and calcite decreased, as did $\mathrm{pH}$. Reduction of $\mathrm{pH}$ resulted in the precipitation of $\mathrm{Ca}(\mathrm{OH})_{2}$ but also leaching of $\mathrm{NaOH}$ by exchange reactions as the charged colloid (such as $\mathrm{Al}(\mathrm{OH})_{6}{ }^{3-}$ ) was a regulator for cation exchange (Kong et al., 2017). As a result, exchangeable sodium percentage decreased. In addition, sodium ions could not be coordinated with negatively charged surfaces which led to the formation of alkaline dust, reduction on erosion resistance and a poor physical structure (Zhu et al., 2016d).

Linear regression analysis showed that the value of clay dispersion ratio (CDR) was positively correlated to clay content, $\mathrm{pH}$ and exchangeable $\mathrm{Na}^{+}$content $(\mathrm{r}=0.898,0.943$, and 0.826 respectively; $P<0.01)$, but negatively correlated to exchangeable $\mathrm{Ca}^{2+}$ and total organic carbon content $(\mathrm{r}=-0.972$ and $-0.936, P<0.01$ ) (Fig. 4). The value of aggregated silt and clay (ASC) was negatively correlated to clay content, $\mathrm{pH}$ and exchangeable $\mathrm{Na}^{+}$content $(\mathrm{r}=-0.903,-0.927$, and -0.865 , respectively; $P<0.01)$, and positively correlated to exchangeable $\mathrm{Ca}^{2+}$ and total organic carbon content $(\mathrm{r}=0.948$ and 0.932 respectively, $P<0.01$ ) (Fig. 5). This indicated that high exchangeable $\mathrm{Ca}^{2+}$ content and low exchangeable $\mathrm{Na}^{+}$stimulated microaggregate flocculation, whilst the decrease in $\mathrm{pH}$ and the accumulation of organic carbon may have improved microaggregate stability. Courtney et al. (2009) established a field scale investigation to promote vegetation cover on bauxite residue, and found that spent mushroom compost and gypsum amendments decreased $\mathrm{pH}$ and ESP which positively impacted on microaggregate stability. Addition of $\mathrm{Ca}$ had a positive effect on flocculating clay particles, reducing mechanical dispersion and lowering exchangeable $\mathrm{Na}^{+}$content, thereby stabilizing microaggregates (Harris \& Rengasamy, 2004). Pojasok \& Kay (1990) reported that increasing organic carbon content stimulated particle aggregation.

\section{Single-fractal Features of Residue Microaggregates}

The fractal dimension of soil microaggregates may reflect the geometry parameters of soil aggregate structure, with higher clay content indicating the higher value of the fractal dimension (D). Under natural weathering processes, residue fractal dimension (D) was significantly affected (Fig. 6). The single-fractal dimension ranged from 2.2 to 2.4 and with increasing disposal age, microaggregate fractal dimension (D) decreased. R1 had a low proportion of 250-20 $\mu \mathrm{m}$ size 
aggregates and a high proportion of 10-2 $\mu \mathrm{m}$ aggregates, which resulted in a high fractal dimension value. Under natural soil forming processes, fine particle aggregation led to the decrease in single-fractal dimensions. Certainly, single-fractal dimension (D) was positively correlated with the proportion of $10-5 \mu \mathrm{m}, 5-2 \mu \mathrm{m}$, and $<2 \mu \mathrm{m}$ sized microaggregates $(\mathrm{r}=0.859$, $0.977,0.991$ respectively, $P<0.01$ ), but negatively correlated with the proportion of $250-50 \mu \mathrm{m}$ and 50-20 $\mu \mathrm{m}$ sized microaggregates $(\mathrm{r}=0.876$ and 0.761 respectively, $P<0.01)$. There was no significant correlation between single-fractal dimension and the proportion of $20-10 \mu \mathrm{m}$ sized microaggregates. Single-fractal dimension may be regarded as an important indicator to reflect aggregate structure of bauxite residue.

High alkalinity and salinity resulted in poor aggregate structure of the residue and clearly affected revegetation on disposal areas (Jones et al., 2011). Zhu et al. (2016d) found that natural vegetation encroachment ameliorated residue physicochemical properties and stimulated aggregate stability. Courtney et al. (2013) investigated the physical condition of revegetated residue and found that gypsum and organic carbon decreased $\mathrm{pH}$ and ESP, which enhanced the proportion of water-stable aggregates, which supported plant growth. The related relationships between single-fractal dimension and $\mathrm{pH}, \mathrm{EC}$, and ESP are displayed in Fig. 7. The single-fractal dimension was positively correlated with $\mathrm{pH}$, ESP, exchangeable $\mathrm{Na}^{+}$content and $\mathrm{EC}(\mathrm{r}=0.935$, $0.984,0.859$ and 0.912 respectively, $P<0.01$ ), but negatively correlated with exchangeable $\mathrm{Ca}^{2+}$ content $(\mathrm{r}=-0.968, \quad P<0.01)$. It indicated that the single-fractal dimension of residue microaggregates may reflect the related physical and chemical properties of bauxite residue.

\section{Multi-fractal Dimension of Residue Microaggregates}

Multi-fractal spectrums of residue microaggregate size distributions between -10 and 10 at 1.0 lag increments for different disposal ages are presented in Fig. 8. The multi-fractal spectrums show a typical anti-S-decreasing function. The information entropy $\left(\mathrm{D}_{(\mathrm{q})}\right)$ of residue microaggregates decreased with increasing disposal age. Furthermore, in each residue sample, $\mathrm{D}_{0}>\mathrm{D}_{1}$ always existed, meaning that microaggregate size distribution with different disposal ages were not homogeneous or monofractal. Therefore, multi-fractal dimension analysis was essential.

The value of $D_{0}, D_{1}$ and $D_{1} / D_{0}$ decreased with increasing disposal age (Table III). In residues which had been stacked for 20 years (R5), these values were nearly the lowest $\left(D_{0}, D_{1}\right.$ and $D_{1} / D_{0}$ values of $0.942,0.853$ and 0.906 , respectively), whilst for $R 1$, these values were the highest $\left(\mathrm{D}_{0}, \mathrm{D}_{1}\right.$ and $\mathrm{D}_{1} / \mathrm{D}_{0}$ values of $0.968,0.891$ and 0.920 , respectively). Analysis of variance in the different residues showed that the multi-fractal parameters of R1 and R2 were significantly different $(P<0.05)$.

The larger $\mathrm{D}_{0}$ means a wider range of microaggregate size distributions. Nevertheless, the calculation of $\mathrm{D}_{0}$ is based on the assumption that particle size distribution was homogeneous. The value of $\mathrm{D}_{1} / \mathrm{D}_{0}$ may make a quantitative description of the heterogeneous degree of soil particle size distribution. Miranda et al. (2006) pointed out that if the value of $\mathrm{D}_{1} / \mathrm{D}_{0}$ was closer to 1 this specified that the particle size distribution was more concentrated. The value of $\mathrm{D}_{1} / \mathrm{D}_{0}$ in the residue microaggregates ranged from 0.896 to 0.920 . With increasing disposal age, the value of $\mathrm{D}_{1} / \mathrm{D}_{0}$ decreased indicating that natural weathering processes decreased the concentration of microaggregate distribution. Natural processes accumulate organic carbon over time and this may have ameliorated the high alkalinity and salinity in the residue, stimulating fine particle aggregation. A significant increase in the proportion of 250-50 $\mu \mathrm{m}$ residue microaggregates resulted in homogeneity with increasing disposal age. 
Bivariate correlation analysis between multi-fractal parameters and residue microaggregate distribution showed that the value of $\mathrm{D}_{0}, \mathrm{D}_{1}, \mathrm{D}_{1} / \mathrm{D}_{0}$ was significantly correlated with the proportion of $<2 \mu \mathrm{m}$ microaggregates $(\mathrm{r}=0.915,0.786$ and 0.523 respectively, $P<0.05)$. In addition, the value of $\mathrm{D}_{1}$ was positively correlated with the proportion of $10-5 \mu \mathrm{m}$ and 5-2 $\mu \mathrm{m}$ microaggregates $(\mathrm{r}=0.912$ and 0.671 respectively, $P<0.05)$. According to correlation analysis between multi-fractal parameters, $\mathrm{D}_{1}$ was positively correlated with $\mathrm{D}_{0}$ and $\mathrm{D}_{1} / \mathrm{D}_{0}(\mathrm{r}=0.933$ and 0.917 respectively, $P<0.05)$. Multi-fractal parameters of residue microaggregate size distribution were mainly affected by the proportion of $<10 \mu \mathrm{m}$ microaggregates, especially the silt-sized $(<2 \mu \mathrm{m})$ microaggregates.

Multi-fractal dimension of residue microaggregates was closely linked with related physicochemical properties. Residues which had been stacked for 20 years had a low $\mathrm{pH}$ and EC which led to a low multi-fractal dimension, whilst the newly stacked residue had a high $\mathrm{pH}$ and $\mathrm{EC}$ and a high multi-fractal dimension. This suggested that the multi-fractal parameters of microaggregates may reflect physical and chemical properties and may be used as an effective indicator to characterize alkalinity and salinity of bauxite residue. According to multiple linear models between multi-fractal parameters and the related properties of bauxite residue, the following equations were obtained:

$$
\mathrm{D}_{0}=1.01926+0.0018 \mathrm{x}_{1}-0.0079 \mathrm{x}_{2}-0.00376 \mathrm{x}_{3}+2.06 \times 10^{-4} \mathrm{x}_{4}
$$

$$
\begin{aligned}
& \mathrm{D}_{1}=0.91468+0.00325 \mathrm{x}_{1}-0.00476 \mathrm{x}_{2}+1.9669 \times 10^{-4} \mathrm{x}_{3}-3.91826 \times 10^{-4} \mathrm{x}_{4} \\
& \mathrm{D}_{1} / \mathrm{D}_{0}=0.88054+0.00498 \mathrm{x}_{1}-0.0019 \mathrm{x}_{2}+0.00231 \mathrm{x}_{3}+6.58484 \times 10^{-5} \mathrm{x}_{4}
\end{aligned}
$$

where $\mathrm{x}_{1}$ is the content of TOC, $\mathrm{x}_{2}$ is the value of $\mathrm{pH}, \mathrm{x}_{3}$ is the value of $\mathrm{EC}$, and $\mathrm{x}_{4}$ is the value of ESP. This demonstrated that organic carbon content and $\mathrm{pH}$ were the main properties influencing the values of multi-fractal dimension of residue microaggregates.

\section{Relationship between Microaggregate Stability and Fractal Parameters}

Microaggregate stability is usually used to estimate or predict soil erosion and surface runoff (Wang et al., 2016). Bauxite residue has poor physical structure to resist water erosion and support revegetation. Zhu et al. (2016d) discovered that following natural weathering processes, the erodibility factor of the residue decreased indicating improved resistance to erosion. Correlation analysis showed that single- and multi-fractal parameters were significantly correlated to microaggregate stability indicating that fractal parameters of residue microaggregate distribution may reflect microaggregate stability. The fractal dimension of microaggregate size distribution may exhibit variation in microaggregate size distribution. The high value fractal parameters indicated a dense physical structure and poor erosion resistance.

Tang et al. (2013) revealed a significant negative relationship between fractal dimension and soil microaggregate content $(<0.25 \mathrm{~mm})$ in karst rocky desertification areas and suggested that fractal dimension could be used as a reliable indicator of soil quality. A small fractal dimension value for granular structure indicated a stable soil structure. Ahmadi et al. (2011) found that both number- and mass-based fragmentation fractal dimension may describe the aggregate size distribution and estimate splash and inter-rill soil erosion. In our study, the single-fractal dimension (D) of microaggregate distribution was negatively correlated with ASC $(\mathrm{r}=-0.977, P<0.01)$, whilst positively correlated with $\mathrm{CDR}(\mathrm{r}=0.995, P<0.01)$. The value of $\mathrm{D}_{0}$ and $\mathrm{D}_{1}$ showed a significant correlation with ASC $(\mathrm{r}=-0.823$ and -0.739 respectively, $P<0.01)$ and $\mathrm{CDR}(\mathrm{r}=0.822$ and 0.709 respectively, $P<0.01)$, whilst $\mathrm{D}_{0} / \mathrm{D}_{1}$ had 
little significant difference with ASC and CDR (Table IV). With increasing disposal age, aggregation of fine particles resulted in a lower value of fractal dimension and a more stable aggregated structure. This suggests that fractal dimension may be useful to characterize microaggregate stability. Compared to multi-fractal parameters, single-fractal dimension (D) was more significantly correlated with microaggregate stability in bauxite residue.

\section{CONCLUSIONS}

Microaggregate stability, an important physical indicator, is required to sustain a stable physical structure. This study has clearly demonstrated that natural weathering processes significantly affect particle size distribution of residue microaggregates. With increasing disposal age, the proportion of silt- and clay-sized microaggregates significantly decreased. Clay dispersion ratio (CDR) decreased from $22.5 \%$ to $7.7 \%$, and aggregated silt and clay (ASC) increased from $15.3 \%$ to $19 \%$ indicating that natural weathering processes enhanced microaggregate stability. Clay content, organic carbon, exchangeable bases and $\mathrm{pH}$ were significantly correlated with ASC and CDR which indicated that organic carbon and exchangeable cations had significant effects on microaggregate stability. The value for single-fractal dimension (D) varied from 2.2 to 2.4. With increasing disposal age, both single-fractal dimension (D) and multi-fractal parameters $\left(\mathrm{D}_{0}, \mathrm{D}_{1}\right.$ and $\left.\mathrm{D}_{1} / \mathrm{D}_{0}\right)$ decreased, revealing that natural weathering process promoted aggregation of microaggregates. Correlation analyses demonstrated that fractal parameters were significantly correlated with microaggregate stability and physicochemical properties, indicating that fractal parameters may be used to characterize residue physical structure and related properties. This study may help to provide an improved understanding of physical microstructures, appropriate indicators to use when evaluating microaggregate stability, and a scientific basis for the revegetation of bauxite residue disposal areas.

\section{ACKNOWLEDGEMENT}

Financial support from National Natural Science Foundation of China (No. 41371475) and Environmental protection's special scientific research for Chinese public welfare industry (No. 201509048) is gratefully acknowledged.

\footnotetext{
Ahmadi A, Neyshabouri M, Rouhipour H, Asadi H. 2011. Fractal dimension of soil aggregates as an index of soil erodibility. Journal of Hydrology 400: 305-311. DOI: 10.1016/j.jhydrol.2011.01.045.

Aksakal EL, Sari S, Angin I. 2016. Effects of vermicompost application on soil aggregation and certain physical properties. Land Degradation \& Development 18: 1916-1932. DOI:10.1002/ldr.2350.

Barbosa GMDC, Oliveira JFD, Miyazawa M, Ruiz DB, Filho JT. 2015. Aggregation and clay dispersion of an oxisol treated with swine and poultry manures. Soil and Tillage Research 146: 279-285. DOI: 10.1016/j.still.2014.09.022.

Cammeraat LH, Imeson AC. 1998. Deriving indicators of soil degradation from soil aggregation studies in southeastern Spain and southern France. Geomorphology 23: 307-321. DOI: 10.1016/S0169-555X(98)00012-9.

Cerdà A. 2000. Aggregate stability against water forces under different climates on agriculture land and scrubland in southern
} 
Bolivia. Soil \& Tillage Research 57: 159-166. DOI: 10.1016/S0167-1987(00)00155-0.

Courtney RG, Jordan SN, Harrington T. 2009. Physico-chemical changes in bauxite residue following application of spent mushroom compost and gypsum. Land Degradation \& Development 20: 572-581. DOI: 10.1002/ldr.926.

Courtney R, Harrington T, Byrne KA. 2013. Indicators of soil formation in restored bauxite residues. Ecological Engineering 58: 63-68. DOI: 10.1016/j.ecoleng.2013.06.022.

Garcia-Franco N, Martínez-Mena M, Goberna M, Albaladejo J. 2015. Changes in soil aggregation and microbial community structure control carbon sequestration after afforestation of semiarid shrublands. Soil Biology \& Biochemistry 87: 110-121. DOI: $10.1016 /$ j.soilbio.2015.04.012

Gao GL, Ding GD, Zhao YY, Wu B, Zhang YQ, Qin SG, Bao YF, Yu MH, Liu YD. 2014. Fractal approach to estimating changes in soil properties following the establishment of Caragana korshinskii, shelterbelts in Ningxia, NW China. Ecological Indicators 43: 236-243. DOI: 10.1016/j.ecolind.2014.03.001.

Gelencsér A, Kováts N, Turóczi B, Rostási A, Hoffer A, Imre K, Nyirő-Kósa I, Csákberényi-Malasics D, Tóth A, Czitrovszky A, Nagy A, Nagy S, Ács A, Kovács A, Ferincz A, Hartyáni Z, Pósfai M. 2011. The red mud accident in Ajka (Hungary): characterization and potential health effects of fugitive dust. Environmental Science \& Technology 45: 1608-1615. DOI: $10.1021 / \mathrm{es} 104005 \mathrm{r}$

Goloran JB, Phillips IR, Chen CR. 2016. Forms of nitrogen alter plant phosphorus uptake and pathways in rehabilitated highly alkaline bauxite processing residue sand. Land Degradation \& Development. DOI: 10.1002/ldr.2630.

Rodríguez-Lado L, Lado M. 2016. Relation between soil forming factors and scaling properties of particle size distributions derived from multifractal analysis in topsoils from Galicia (NW Spain). Geoderma. DOI: 10.1016/j.geoderma.2016.08.005.

Harris MA, Rengasamy P. 2004. Sodium affected subsoils, gypsum, and green-manure: Inter- actions and implications for amelioration of toxic red mud wastes. Environmental Geology 45: 1118-1130. DOI: 10.1007/s00254-004-0970-y.

Igwe CA, Zarei M, Stahr K. 2009. Colloidal stability in some tropical soils of southeastern Nigeria as affected by iron and aluminium oxides. Catena 77: 232-237. DOI: 10.1016/j.catena.2009.01.003.

Jing J, Feng P, Wei S, Zhao H, Liu Y. 2016. Investigation on the surface morphology of $\mathrm{Si}_{3} \mathrm{~N}_{4}$ ceramics by a new fractal dimension calculation method. Applied Surface Science 387: 812-821. DOI: 10.1016/j.apsusc.2016.06.181.

Jones BEH, Haynes RJ, Phillips IR. 2011. Influence of organic waste and residue mud additions on chemical, physical and microbial properties of bauxite residue sand. Environmental Science and Pollution Research 18: 199-211. DOI: $10.1007 / \mathrm{s} 11356-010-0364-5$.

Kaur N, Phillips I, Fey MV. 2016. Amelioration of bauxite residue sand by intermittent additions of nitrogen fertiliser and leaching fractions: the effect on growth of kikuyu grass and fate of applied nutrients. Science of the Total Environment 550: 362-371. DOI: 10.1016/j.scitotenv.2016.01.012.

Kong XF, Guo Y, Xue SG, William H, Wu C, Ye YZ, Cheng QY. 2017a. Natural evolution of alkaline characteristics in bauxite residue. Journal of Cleaner Production 143: 224-230. DOI: 10.1016/j.jclepro.2016.12.125.

Kong XF, Li M, Xue SG, William H, Chen CR, Wu C, Li XF, Li YW. 2017b. Acid transformation of bauxite residue: conversion of its alkaline characteristics. Journal of Hazardous Materials 324: 382-390. DOI: 10.1016/j.jhazmat.2016.10.073.

Le Guillou C, Angers DA, Maron PA, Leterme P, Menasseri-Aubry S. 2012. Linking microbial community to soil water-stable aggregation during crop residue decomposition. Soil Biology and Biochemistry 50: 126-133. DOI: 10.1016/j.soilbio.2012.03.009.

Lehmann A, Rillig MC. 2015. Understanding mechanisms of soil biota involvement in soil aggregation: a way forward with saprobic fungi? Soil Biology and Biochemistry 88: 298-302. DOI: 10.1016/j.soilbio.2015.06.006.

Li B, Liu R, Jiang Y. 2016. A multiple fractal model for estimating permeability of dual-porosity media. Journal of Hydrology 540: 659-669. DOI: 10.1016/j.jhydrol.2016.06.059.

Liu Y, Naidu R, Ming H. 2013. Surface electrochemical properties of red mud (bauxite residue): zeta potential and surface charge density. Journal of Colloid and Interface Science 394: 451-457. DOI: 10.1016/j.jcis.2012.11.052. 
Mbagwu JSC, Auerswald K. 1999. Relationship of percolation stability of soil aggregates to land use, selected properties, structural indices and simulated rainfall erosion. Soil \& Tillage Research 50: 197-206. DOI: 10.1016/S0167-1987(99)00006-9.

Miranda JGV, Montero E, Alves MC, González AP, Vázquez EV. 2006. Multifractal characterization of saprolite particle-size distributions after topsoil removal. Geoderma 134: 373-385. DOI: 10.1016/j.geoderma.2006.03.014.

Moncada MP, Gabriels D, Cornelis W, Lobo D. 2013. Comparing aggregate stability tests for soil physical quality indicators. Land Degradation \& Development 26: 843-852. DOI: 10.1002/ldr.2225.

Monreal CM, Schnitzer M, Schulten HR, Campbell CA, Anderson DW. 1995. Soil organic structures in macro and microaggregates of a cultivated Brown Chernozem. Soil Biology and Biochemistry 27: 845-853. DOI: 10.1016/0038-0717(94)00220-U.

Peng G, Xiang N, Lv S, Zhang G. 2014. Fractal characterization of soil particle-size distribution under different land-use patterns in the Yellow River Delta Wetland in China. Journal of Soils and Sediments 14: 1116-1122. DOI: $10.1007 / \mathrm{s} 11368-014-0876-6$.

Pojasok T, Kay BD. 1990. Assessment of a combination of wet sieving and turbidimetry to characterize the structural stability of moist aggregates. Canadian Journal of Soil Science 70: 33-42. DOI: 10.4141/cjss90-004.

Rillig MC, Wright SF, Kimball BA, Pinter PJ, Wall GW, Ottman MJ, Leavitt SW. 2001. Elevated carbon dioxide and irrigation effects on water stable aggregates in a Sorghum field: a possible role for arbuscular mycorrhizal fungi. Global Change Biology 7: 333-337. DOI: 10.1046/j.1365-2486.2001.00404.x.

Ruyters S, Mertens J, Vassilieva E, Dehandschutter B, Poffijn A, Smolders E. 2011. The red mud accident in Ajka (Hungary): plant toxicity and trace metal bioavailability in red mud contaminated soil. Environmental Science \& Technology $\mathbf{4 5}$ : 1616-1622. DOI: $10.1021 / \mathrm{es} 104000 \mathrm{~m}$.

Santini TC, Fey MV. 2013. Spontaneous vegetation encroachment upon bauxite residue (red mud) as an indicator and facilitator of in situ remediation processes. Environmental Science \& Technology 47: 12089-12096. DOI: 10.1021/es402924g.

Schmalenberger A, O Sullivan O, Gahan J, Cotter PD, Courtney R. 2013. Bacterial communities established in bauxite residues with different restoration histories. Environmental Science \& Technology 47: 7110-7119. DOI: 10.1021/es401124w.

Smart D, Callery S, Courtney R. 2016. The potential for waste-derived materials to form soil covers for the restoration of mine tailings in Ireland. Land Degradation \& Development 27: 542-549. DOI: 10.1002/ldr.2465.

Kolay E, Kayabali K. 2006. Investigation of the effect of aggregate shape and surface roughness on the slake durability index using the fractal dimension approach. Engineering Geology 86: 271-284. DOI: 10.1016/j.enggeo.2006.05.007.

Singer MJ, Southard RJ, Warrington DN, Janitzky P. 1992. Stability of synthetic sand-clay aggregates after wetting and drying cycles. Soil Science Society of America Journal 56: 1843-1848. DOI:10.2136/sssaj1992.03615995005600060032x.

Tang Y, Li J, Zhang X, Yang P, Wang J, Zhou N. 2013. Fractal characteristics and stability of soil aggregates in karst rocky desertification areas. Natural Hazards 65: 563-579. DOI: 10.1007/s11069-012-0383-2.

Tyler SW, Wheatcraft SW. 1989. Application of fractal mathematics to soil water retention estimation. Soil Science Society of America Journal 53: 987-996. DOI:10.2136/sssaj1989.03615995005300040001x.

Virto I, Barré P, Chenu C. 2008. Microaggregation and organic matter storage at the silt-size scale. Geoderma 146: 326-335. DOI: 10.1016/j.geoderma.2008.05.021.

Wang J, Yang W, Yu B, Li Z, Cai C, Ma R. 2016. Estimating the influence of related soil properties on macro- and micro-aggregate stability in ultisols of south-central China. Catena 137: 545-553. DOI: 10.1016/j.catena.2015.11.001.

Wang J, Zhang M, Bai Z, Guo L. 2015. Multi-fractal characteristics of the particle distribution of reconstructed soils and the relationship between soil properties and multi-fractal parameters in an opencast coal-mine dump in a loess area. Environmental Earth Sciences 73: 4749-4762. DOI: 10.1007/s12665-014-3761-0.

Wei X, Li X, Wei N. 2016. Fractal features of soil particle size distribution in layered sediments behind two check dams: Implications for the Loess Plateau, China. Geomorphology 266: 133-145. DOI: 10.1016/j.geomorph.2016.05.003. 
Wu C, Zou Q, Xue SG, Pan WS, Yue X, William H, Huang L, Mo JY. 2016. Effect of silicate on arsenic fractionation in soils and its accumulation in rice plants. Chemosphere 165: 478-486. DOI: 10.1016/j.chemosphere.2016.09.061.

Xue SG, Kong XF, Zhu F, William H, Li XF, Li YW. 2016a. Proposal for management and alkalinity transformation of bauxite residue in China. Environmental Science and Pollution Research 23: 12822-12834. DOI: 10.1007/s11356-016-6478-7.

Xue SG, Zhu F, Kong XF, Wu C, Huang L, Huang N, William H. 2016b. A review of the characterization and revegetation of bauxite residues (Red mud). Environmental Science and Pollution Research 23: 1120-1132. DOI: $10.1007 / \mathrm{s} 11356-015-4558-8$.

Yagüe MR, Domingo-Olivé F, Bosch-Serra ÀD, Poch RM, Boixadera J. 2016. Dairy cattle manure effects on soil quality: porosity, earthworms, aggregates and soil organic carbon fractions. Land Degradation \& Development. DOI:10.1002/ldr.2477.

Zhou Q, Bao Y, Liu W. 2017. Ecological Geoscience. Beijing: Science Press (in Chinese).

Zhou Q, Sun F, Liu R. 2005. Joint chemical flushing of soils contaminated with petroleum hydrocarbons. Environment International 31: 835-839. DOI: 10.1016/j.envint.2005.05.039.

Zhu F, Huang N, Xue SG, William H, Li YW, Zou Q. 2016a. Effects of binding materials on microaggregate size distribution in bauxite residues. Environmental Science and Pollution Research 23: 23867-23875. DOI: 10.1007/s11356-016-7626-9.

Zhu F, Liao JX, Xue SG, William H, Zou Q, Wu H. 2016b. Evaluation of aggregate microstructures following natural regeneration in bauxite residue as characterized by synchrotron-based X-ray micro-computed tomography. Science of The Total Environment 573: 155-163. DOI: 10.1016/j.scitotenv.2016.08.108.

Zhu F, Xue SG, William H, Huang L, Wu C, Li XF. 2016c. Novel predictors of soil genesis following natural weathering processes of bauxite residues. Environmental Science and Pollution Research 23: $2856-2863.2$ DOI: $10.1007 / \mathrm{s} 11356-015-5537-9$.

Zhu F, Zhou JY, Xue SG, William H, Wu C, Guo Y. 2016d. Aging of bauxite residue in association of regeneration: a comparison of methods to determine aggregate stability \& erosion resistance. Ecological Engineering 92: 47-54. DOI: 10.1016/j.ecoleng.2016.03.025.

Zhu F, Hou JT, Xue SG, Wu C, Wang QL, William H. 2017. Vermicompost and gypsum amendments improve aggregate formation in bauxite residue. Land Degradation \& Development. DOI: 10.1002/ldr.2737. 